\title{
The Effect of Mentor Training Program on Competence and Attitude Regarding Mentorship
}

\author{
Meltem YALIN UCAR ${ }^{1}$
}

\begin{abstract}
In this study, the developed "Mentor Training Program" was applied among a group of mentor candidates to provide mentors with mentorship competences and positive attitudes and to gain insight into the effect of the training program on the process. The study was carried out with longitudinal method. The research was initiated in 2007 with "Mentor Training Program" and the effect of acquired mentorship competencies and positive attitude on mentors were investigated for this period. The study group consists of 10 male and 5 female school teachers serving in primary schools operating under Aydın Provincial Directorate of National Education. Mentor Training Program was found to be effective on the subject of "competence" in the short and medium terms, while it was partly effective in the long term. The training program proved to be effective on the subject of "attitude" with relation to practice teaching in the short, medium and long terms.
\end{abstract}

Keywords: Mentor Training Program, Mentor, Mentor Attitude and Mentorship Competence

\section{INTRODUCTION}

In the international literature, "mentor (master teacher)" is not related to teaching the profession, but preparing teacher candidates for practice as a professional during the course of their pre-service training process. The term "mentor" covers peer management in formal terms, and relates to professionals who support and aid teacher candidates. Mentorship, on the other hand, covers constituents of all professional applications that bring teacher candidate's potential to higher levels (Ambrosetti, Knight, \& Dekkers, 2014). These constituents involve variables such as training guidance provided for teacher candidates by practicing teachers in classroom environment, an effective practicing environment, curriculum development, and enabling teacher candidates to be reflective in their fields (AERA, 2005). The concept of "mentorship" addressed in this study relates not only to the task of teacher candidate training, but also to fulfillment of the roles and responsibilities undertaken by teacher candidates, in addition to the responsibility of primary school teaching. Mentors' tasks, roles and responsibilities involve enabling teachers to have a controlled and positive initial experience as to their profession in real environments and contribute to their professional competency through making them look over their teaching skills. A successful mentoring process is also about inclusion of successful teacher candidates in the educational system. Teachers' success, knowledge and teaching activities in classroom environment are crucial factors for achievement of a successful education (Breaux \& Wong, 2003; AERA, 2005; Wong, 2004). Accordingly, as a requirement of university-school cooperation reform, mentor-teacher candidate interaction process is supported to improve the teaching quality for primary school students (Moir \& Gless, 2004; Odell, Huling, \& Sweeny, 1999).

As stated in previous studies, mentoring support increases the motivation of teacher candidates as to their profession, provided it remains within the frame of communication required for adult education (Smith, Hofer, Gillespie, Solomon, \& Rowe, 2003); and teacher candidates planning their practicing period with their mentors (facilitative mentoring support) benefit from their mentors to higher extents

\footnotetext{
${ }^{1}$ Dr. Adnan Menderes University, Curriculum and Insruction, myalinuc@gmail.com
} 
as compared to other teacher candidates (Clark, 2012). Mentoring support has been used in Europe and particularly in USA to increase the quality of teaching and ensure its permanence for long periods, and in this context, professional mentor training programs are developed. The results of related studies (AERA, 2005; AIR, 2015; Iris \& Sadlin, 2002; Strong, 2005) indicate that, training teacher candidates with mentor training program yields positive outcomes for teaching candidates as to their teaching practice period. Also, the particular importance attached to the relationship between practicing teachers and teacher candidates in recent years have required mentors to be well-equipped regarding their mentoring responsibilities (Sutherland, Scanlon, \& Sperring, 2005). This, in turn, brought about the necessity for mentors to acquire their mentoring roles and responsibilities via formal training programs. The process of teaching practice is also formal, as it is an extension of teacher training in which its theoretical dimension is put into practice; and this requires restructuring of the process. Once mentors, that have close relationship with teacher candidates, are equipped with competences with relation to practice teaching, teacher training's practice process will gain a professional value as its theoretical process. Also, the positive attitude gained by teacher candidates as to their responsibility throughout this support period will both have a positive influence on their practice process and provide them with a positive understanding of teaching profession. The development and evaluation of mentor training program, initiated as a result of the needs analysis conducted in various regions and provinces of the country, is yet to be concluded. Accordingly, the mentor training program was developed in the current study with a view to train mentors to achieve specific objectives, and provide them with qualified practice experience, thus increasing the quality of primary school teaching. During this practicing process which is based on specific principles, guiding mentors provide teacher candidates with an insight into their teaching theories, approaches, classroom management and program policies through dialogue and reflectiveness. Such focusing is reflected upon intra-class practices and concludes with the achievement of student development, thus resulting in new content field (Smith et al., 2003). Mentoring period yields a learning environment among teacher candidates and mentors, which in turn develops a problem solving behavior among them. This way, both mentors' and teacher candidates' students are likely to benefit from the skills developed during mentoring process. Previous studies indicate that, students learning outcomes is strongly affected teaching quality (Rivkin \& Hanusek, 2005; Rockoff, 2004).

As a consequence of the abovementioned reasons, the teaching program was developed in line with national requirements. Compliance of the developed Mentor Training Program with cultural attributes holds great importance, since mentor training programs are generally criticized for their being avoid of social validity (Duckworth \& Maxwell, 2015; Gershenfeld, 2014;).

Another valuable aspect of this study is development and implementation of the training program in line with the principles of "adult education". According to the research reports released on a regular basis by American Research Institute, both mentor training and mentors' interaction with teacher candidates should be in compliance with adult education principles (AIR, 2015). Also, predetermined targetbehaviors, teaching methods and evaluation tools render the training program repeatable and assessable. In a study investigating the mentor training programs implemented in 2008-2012 period in terms of definition, theory and method the implemented programs were reported to have not been subjected to preliminary implementation and $75 \%$ of these programs were reported to be unrepeatable (Gershenfeld, 2014). However, Jacobi (1991) suggested that, these programs should be subjected to thor- 
ough research patterns to make them repeatable and understand their academic success (Cited in Gerhenfeld, 2014). Formally developed in line with the national requirements, this program will contribute to achievement of the process of teaching practice in accordance with predetermined objectives, thus eliminating ambiguities as to the process. The objectives established at a national level will ensure accomplishment of teacher training process within the frame of national needs, and contribute to acquisition of more realistic, applicable and favorable results. Also the standards established in relation to the process of teaching practice will yield a higher teaching quality in addition to improved student success.

A mentor training program specifically designed for Turkey, especially in line with a "needs analysis" performed at a national level, is yet to be developed. The "mentor training program" developed in the present study was applied among a group of mentor candidates to provide them with competency and positive attitude as to mentoring with an attempt to understand its effect throughout the process. In the research, the concepts of "mentor" and "practicing teacher" bear the same meaning.

\section{METHOD}

The study was carried out using longitudinal method. Longitudinal research aims to understand the changes in individuals, specific events and moods or evaluations and monitor such changes or developments by means of qualitative or quantitative data (Farall, 2015).

In this study, the effect of competences and positive attitudes gained by mentors in 2007 by "Mentor Training Program" was investigated for the period as from this year to understand whether a change occurred in practicing teachers' competence and attitude levels.

The study consists of seven different stages:

1. In the first stage a "needs analysis" was performed for the Mentor Training Program.

2. In the second stage, Mentor Training Program was developed.

3. In the third stage, Mentor Training Program was implemented experimentally.

4. In the fourth stage, the implementation (2007) and post-implementation period of Mentor Training Program was evaluated.

5. In the fifth stage, monitoring tests of Mentor Training Program, belonging to two years after (2009) the implementation were applied and evaluated.

6. In the sixth stage, monitoring tests of Mentor Training Program, belonging to two years after (2012) the implementation were applied and evaluated.

7. In the seventh stage, monitoring tests of Mentor Training Program, belonging to two years after (2015) the implementation were applied and evaluated.

The "Mentor Training Program" with above stages was investigated in terms of its effectiveness in the short, medium and long terms.

\section{Study Group}

Study group of the research consists of 5 female and 10 male teachers serving in primary education schools which are affiliated to Aydın Provincial Directorate for National Education. Teaching experience 
of the study group varies between 10 and 25 years. 30 hours of "mentor training program" was implemented on the participants of the research within 05.03.2007-16.03.2007 period. In years 2009, 2012, 2013 and 2015, the same participants of the research were also subjected to "mentor competency" and "mentoring attitude" questionnaires to evaluate the permanence of "mentor training program". 2007 experimental phase of the research consists of the experimental model with pretest-posttest control group.

\section{Tools Used in the Research}

\section{Practicing Teacher Training Program (PTTP)}

Practicing Teacher Training Program was developed by the researcher. Needs analysis and experimental stages of the training program was supported by TUBITAK (Scientific and Technological Research Council of Turkey) (2006) and Ministry of National Education EARGED (Department of Research and Development) (2006).

Needs Analysis Stage of the Training Program. Needs analysis of the program was performed within a period of one year through acquisition of the qualitative and quantitative data from all geographical regions of Turkey. During the needs analysis process, data diversification was applied to determine the real educational needs of mentors.

Qualitative Sample Group and Findings of Qualitative Analysis in the Mentor Training Program. Qualitative research data were obtained from Bursa, Ankara, Adana, Aydin, Bolu, Van and Samsun provinces which are located in eastern, western and central Anatolia regions of the country. Face to face individual and group interviews were made with 86 classroom teachers and 22 school managers who undertook the task of practice teaching for at least once in the state primary schools of these cities (Table 1). During the interviews, teachers and school managers were asked about the "properties, qualities and competences that a mentor is supposed to possess", and the responses were recorded in written form.

Table 1.

Qualitative Data Sample Table of Research

\begin{tabular}{llll}
\hline Provinces & Practicing Teachers & School Managers & Total \\
\hline Ankara & 12 & 3 & 25 \\
Adana & 14 & 3 & 21 \\
Aydın & 10 & 3 & 18 \\
Van & 18 & 3 & 26 \\
Samsun & 8 & 3 & 15 \\
Bolu & 10 & 4 & 21 \\
Bursa & 14 & 3 & 22 \\
Total & 86 & 22 & 108 \\
\hline
\end{tabular}


Qualitative data were obtained from a total of 108 educators that undertook an active role in primary education period. The data obtained from interviews were analyzed using "qualitative descriptive" method and the following sub-themes and super-themes were reached:

1. "TIME" theme, which is allocated by classroom teacher for teacher candidates

2. "AFFECTIVE" super-theme related to the affection of classroom teacher for his/her profession and "personal attributes" sub-theme associated with this theme.

3. The theme related to the "LEGAL" regulations regarding mentorship.

4. "COMMUNICATION" (with teacher candidate) super-theme and "observation" sub-theme associated with this theme.

5. "QUANTITY" theme which is related to the number of teacher candidates for one mentor.

6. The theme relating to the necessity for receiving a "TRAINING" as to mentorship, and in this context "mentorship training requirement" sub-theme.

7. "RESPONSIBILITY" of Teaching Practice super-theme and accordingly, "affective factors" sub-theme.

8. Super-theme for the "TASKS" of practicing teachers and correspondingly "fulfillment of academic competency" sub-theme.

9. Super-theme for the ROLES of practicing teachers, and accordingly "communication" sub-theme.

Quantitative Sample Group and Findings of Quantitative Analysis in the Mentor Training Program. The needs analysis quantitative data collection stage of Training Program was performed through drawing data from 14 different cities (Table 2) in seven different geographical regions. 814 mentors serving at 110 primary schools (Table 2) were included in the research. These 814 mentors were subjected to "Practicing Teacher Competency Questionnaire" to obtain the quantitative data, and their frequency analysis was performed using SPSS 11 software package. "Practicing Teacher Competency Questionnaire" was developed by the researcher in 2006 with 5-likert scale. During data analysis, evaluation tool was converted to "three-likert scale".

\section{Table 2.}

Quantitative Data Sample Table of Research

\begin{tabular}{|c|c|c|c|c|c|}
\hline Region & Province & $\begin{array}{l}\text { Number of } \\
\text { Teachers }(\mathrm{N})\end{array}$ & $\begin{array}{l}\text { Number of } \\
\text { Primary } \\
\text { Schools }\end{array}$ & $\begin{array}{l}\text { The number of } \\
\text { evaluated ques- } \\
\text { tionnaires }\end{array}$ & Total \\
\hline \multirow[b]{2}{*}{ Eastern Anatolia } & Erzurum & 55 & 8 & 55 & \multirow[b]{2}{*}{127} \\
\hline & Elazı̆̆ & 72 & 9 & 72 & \\
\hline \multirow[b]{2}{*}{ Black Sea } & Zonguldak & 48 & 7 & 48 & \multirow[b]{2}{*}{97} \\
\hline & Bolu & 49 & 7 & 49 & \\
\hline
\end{tabular}




\begin{tabular}{llllll} 
& Edirne & 53 & 10 & 53 & 184 \\
Marmara & Sakarya & 46 & 7 & 46 & \\
& Çanakkale & 85 & 7 & 85 & 123 \\
Mediterranean & Burdur & 28 & 4 & 28 & \\
& Adana & 95 & 10 & 95 & 125 \\
\hline Aegean & İzmir & 84 & 10 & 84 & 68 \\
\hline Southeastern & Aydın & 41 & 6 & 41 & \\
Anatolia & Siirt & 42 & 7 & 42 & 914 \\
\hline Central Anatolia & Ankara & 90 & 4 & 26 & 90 \\
\hline TOTAL & 14 & 814 & 110 & 814 & \\
\hline
\end{tabular}

In the needs analysis the responses of participants as to the fields of competence that should be possessed by mentors are given in Table 3 .

Table 3.

Fields of Competence That A Mentor Should Possess

\begin{tabular}{lllll}
\hline Fields of Competence & $\mathrm{N} / \%$ & Somewhat necessary & Necessary & Very Necessary \\
\hline Preparedness for Teaching Practices & $\mathrm{N}$ & 148 & 528 & 156 \\
\hline Counseling & $\%$ & 17.8 & 63.5 & 18.8 \\
\hline \multirow{2}{*}{ Evaluation } & $\mathrm{N}$ & 146 & 510 & 176 \\
\hline \multirow{2}{*}{ Observation } & $\%$ & 17.5 & 61.3 & 21.2 \\
\hline Adult Education & $\mathrm{N}$ & 173 & 495 & 164 \\
& $\%$ & 20.8 & 59.5 & 19.7 \\
\hline Classroom Management & $\mathrm{N}$ & 116 & 550 & 166 \\
& $\%$ & 13.9 & 66.1 & 20 \\
\hline Communication & $\mathrm{N}$ & 51 & 616 & 165 \\
& $\%$ & 6.1 & 74 & 19.8 \\
\hline
\end{tabular}




\begin{tabular}{lllll}
\cline { 2 - 5 } Feedback & $\mathrm{N}$ & 196 & 444 & 192 \\
& $\%$ & 23.6 & 53.4 & 23.1 \\
\hline \multirow{2}{*}{ Personal Attributes } & $\mathrm{N}$ & 178 & 523 & 131 \\
& $\%$ & 21.4 & 62.9 & 15.7 \\
\hline
\end{tabular}

As seen in Table 3, majority of primary school teachers (those who undertook the task of practice teaching for at least once) stated their level of agreement for the fields of competence that should be possessed by a mentor, as "necessary" and "very necessary".

\section{Development Process of the Training Program}

Qualitative and quantitative data covering overall country were obtained through supports of Scientific and Technological Research Council of Turkey (2006) and Ministry of National Education Department of Research and Development (2006) for two different projects carried out by the researcher. Mentor Training Program was developed using these obtained data. The training program was developed as a result of evaluation of qualitative and quantitative data within the frame of nine different learning modules which involve cognitive and affective objectives (Figure 1).

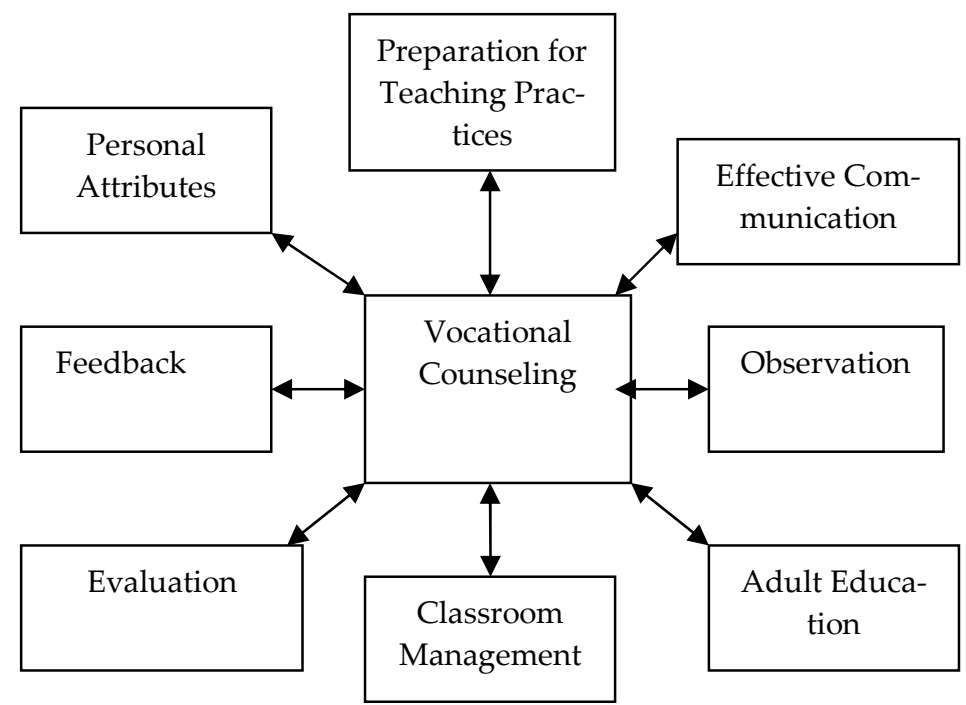

Figure.1. The Training Program

\section{Practicing Period of Mentor Training Program}

The experimental process of the research was performed within 30 course hours using a model with pretest-posttest groups between the dates 05.03.2007-16.03.2007. The study group consists of primary school teachers serving at official primary schools of Aydın Provincial Directorate of National Education. "Mentor Training Program" was applied among 15 groups of primary school teachers (Table 4) with a view to provide them with mentoring qualities. Also, to provide a homogeneous distribution in 
the test group in terms of gender and seniority, the control group (Table 4) was determined with "purposive" sampling method with no education-related intervention.

Table. 4 .

Age, Gender, Seniority and Educational Level of Teachers

\begin{tabular}{lll}
\hline Teachers & Test Group & Control Group \\
\hline Female & 5 & 5 \\
Male & 10 & 10 \\
Age & $35-50$ & $35-50$ \\
Seniority & $10-25$ & $10-25$ \\
Educational level & Associate, Bachelor Degree & Associate, Bachelor Degree
\end{tabular}

Eight different modules of the training program were implemented in course form by academic personnel who are specialized in their fields. In the first course, each participant was given two files. The first file was mentor's working file which included learning modules, target behaviors of these modules and instructions as to how these would be taught in courses. The second file included teacher candidate observation and feedback forms which would be used by the mentor for teacher candidates. The participants in the test group were also given a booklet involving instructive references. Also, during the first course, participants were given a diary with different colors and design for each participant. Participants were asked to write in these diaries their impressions as to the mentor training period and their relationship with teacher candidates, as from the first day of training. During the learning process, several teaching methods were applied including workshops, collaborative education approach and creative drama in accordance with andragogy principles. Due to the limited time, participants were served tea, coffee and snack to fulfill their physical needs during course activities. At the end of each course, positive and negative feedbacks of the training process were received.

\section{Data Collection Tools}

A. Mentor Competence Questionnaire: This measurement tool involves the minimum attributes that a mentor is supposed to have and it is closely associated with the learning modules of the Practicing Teacher Training Program. The measurement tool developed in five likert scale by the researcher in 2006 consists of 100 questions and nine sub-dimensions. The tools coefficient of reliability is .93. The subdimensions used in the tool are as follows: Preparedness for Teaching Practices (13 items, KMO,.91, $\alpha=.90$ ), Vocational Counseling (12 items, KMO,.9, $\alpha=.93$ ), Evaluation (10 items, $\mathrm{KMO}, .92, \alpha=.93$ ), Observation (18 items, KMO,.9 5, $\alpha=.95$ ), Andragogy (7 items, KMO,.88, $\alpha=.92)$, Classroom Management (12 items, KMO,.94, $\alpha=.96$ ), Communication (10 items, KMO,.95, $\alpha=.96$ ), Feedback (6 items, .89, $\alpha=.91$ ), Personal Attributes (12 items, KMO,.94, $\alpha=.94$ ).

B. Practice Teaching Attitude Questionnaire: This measurement tool was developed by the researcher and Zehir (2004) with 30 items in five likert scale. The tool's coefficient of reliability is .87. This 
measurement tool was developed to detect the extent of teachers' positive attitudes with regard to fulfilling their "mentoring tasks and responsibilities".

\section{Data Analysis}

Mann Whitney U-Test was used to make comparison among the groups. Kolmogorov Smirnov test was used for intra-group (single sample) pretest-posttest comparisons. The scores for the attitude levels of the groups before and after the training were obtained using the measurement tool, mean scores and standard deviations were determined and these values were generalized in three dimensions as "negative", "neutral" and "favorable". A frequency analysis was also performed during the research.

\section{FINDINGS}

\section{Evaluation of the Mentor Training Program}

Evaluation of the training program was accomplished using "Practicing Teacher Competence Questionnaire" and the "Questionnaire on Teachers' Attitudes".

The Results Obtained from Practicing Teacher Competence Questionnaire: "Mentor Competence Questionnaire" was applied for the test and the control groups as pretest and posttest.

\section{Table 5.}

Practicing Teacher Competence Pretest Results of Mentor Candidates

\begin{tabular}{|c|c|c|c|c|c|c|c|c|}
\hline Fields of Competence & $\begin{array}{l}\text { Practicing } \\
\text { Teachers }\end{array}$ & $\mathrm{N}$ & $\begin{array}{l}\text { Ranks } \\
\text { Mean. }\end{array}$ & $\begin{array}{l}\text { Ranks } \\
\text { Total. }\end{array}$ & MW-U & $W$ & $Z$ & $p$ \\
\hline \multirow{3}{*}{$\begin{array}{l}\text { Preparedness for Teaching } \\
\text { Practices }\end{array}$} & Test & 15 & 15 & 225 & & & & \\
\hline & Control & 15 & 16 & 240 & 105 & 225 & -0.598 & 0.55 \\
\hline & Total & 30 & & & & & & \\
\hline \multirow{3}{*}{ Vocational Counseling } & Test & 15 & 16 & 240 & & & & \\
\hline & Control & 15 & 15 & 225 & 105 & 225 & -0.392 & 0.695 \\
\hline & Total & 30 & & & & & & \\
\hline \multirow{3}{*}{ Evaluation } & Test & 15 & 15.40 & 231 & & & & \\
\hline & Control & 15 & 15.60 & 234 & 111 & 231 & -0.081 & 0.936 \\
\hline & Total & 30 & & & & & & \\
\hline \multirow{3}{*}{ Observation } & Test & 15 & 14.43 & 216.50 & & & & \\
\hline & Control & 15 & 16.57 & 248.50 & 96.5 & 216.5 & -0.861 & 0.389 \\
\hline & Total & 30 & & & & & & \\
\hline
\end{tabular}




\begin{tabular}{lllllllll} 
& Test & 15 & 15.93 & 239 & & & & \\
Adult Education & Control & 15 & 15.07 & 226 & 106 & 226 & -0.416 & 0.677 \\
& Total & 30 & & & & & & \\
& Test & 15 & 14 & 210 & & & & \\
Classroom Management & Control & 15 & 17 & 255 & 90 & 210 & -1.273 & 0.203 \\
& Total & 30 & & & & & & \\
& Test & 15 & 13.50 & 202.50 & & & & \\
Communication & Control & 15 & 17.50 & 262.50 & 82.5 & 202.5 & -1.523 & 0.128 \\
& Total & 30 & & & & & & \\
Feedback & Test & 15 & 14.50 & 217.50 & & & & \\
& Control & 15 & 16.50 & 247.50 & 97.5 & 217.5 & -0.812 & 0.417 \\
& Total & 30 & & & & & & \\
Personal Attributes & Test & 15 & 14.50 & 217.50 & & & & \\
& Control & 15 & 16.50 & 247.50 & 97.5 & 217.5 & -0.762 & 0.446 \\
& Total & 30 & & & & & & \\
\hline
\end{tabular}

Prior to the mentor training process, no statistically significant difference was observed among the competence perceptions of test and control groups ( $p>.05$ ) (Table 5). This is an indication of the similarity between the mentor competence levels of both groups.

The posttest results of Practicing Teacher Competence Questionnaire performed at the end of two weeks of mentoring program indicate that Mentor Training Program became effective in providing teacher candidates with mentoring competences (Table 6).

\section{Table 6.}

Practicing Teacher Competence-Test Results of Mentor Candidates

\begin{tabular}{lllllllll}
\hline \multirow{2}{*}{ Fields of Competence } & $\begin{array}{l}\text { Practicing Teach- } \\
\text { ers }\end{array}$ & $\mathrm{N}$ & $\begin{array}{l}\text { Ranks } \\
\text { Mean }\end{array}$ & $\begin{array}{l}\text { Ranks } \\
\text { Total }\end{array}$ & $\begin{array}{l}\text { MW- } \\
\text { U }\end{array}$ & W & Z & $\mathrm{p}$ \\
\hline $\begin{array}{l}\text { Preparedness for } \\
\text { Teaching Practices }\end{array}$ & Test & 15 & 23 & 345 & & & & \\
& Control & 15 & 8 & 120 & 0 & 1200 & -4.975 & .00 \\
& Total & 30 & & & & & & \\
\hline \multirow{2}{*}{$\begin{array}{l}\text { Vocational Counsel- } \\
\text { ing }\end{array}$} & Test & 15 & 22.53 & 338 & & & & \\
& Control & 15 & 8.47 & 127 & 70 & 1270 & -4.548 & .00 \\
& Total & 30 & & & & & & \\
\hline
\end{tabular}




\begin{tabular}{|c|c|c|c|c|c|c|c|c|}
\hline & Test & 15 & 23 & 345 & & & & \\
\hline \multirow[t]{3}{*}{ Evaluation } & Control & 15 & 8 & 120 & 0 & 1200 & -5.089 & .00 \\
\hline & Total & 30 & & & & & & \\
\hline & Test & 15 & 22.67 & 340 & & & & \\
\hline \multirow[t]{3}{*}{ Observation } & Control & 15 & 8.33 & 125 & 50 & 1250 & -4.644 & .00 \\
\hline & Total & 30 & & & & & & \\
\hline & Test & 15 & 23 & 345 & & & & \\
\hline \multirow[t]{2}{*}{ Adult Education } & Control & 15 & 8 & 120 & 0 & 1200 & -4.962 & .00 \\
\hline & Total & 30 & & & & & & \\
\hline \multirow{3}{*}{$\begin{array}{l}\text { Classroom Manage- } \\
\text { ment }\end{array}$} & Test & 15 & 23 & 345 & & & & \\
\hline & Control & 15 & 8 & 120 & 0 & 1200 & -4.981 & .00 \\
\hline & Total & 30 & & & & & & \\
\hline \multirow{3}{*}{ Communication } & Test & 15 & 23 & 345 & & & & \\
\hline & Control & 15 & 8 & 120 & 0 & 1200 & -5.089 & .00 \\
\hline & Total & 30 & & & & & & \\
\hline \multirow{3}{*}{ Feedback } & Test & 15 & 23 & 345 & & & & \\
\hline & Control & 15 & 8 & 120 & 0 & 1200 & -5.109 & .00 \\
\hline & Total & 30 & & & & & & \\
\hline \multirow{3}{*}{ Personal Attributes } & Test & 15 & 23 & 345 & & & & \\
\hline & Control & 15 & 8 & 120 & 0 & 1200 & -4.898 & .00 \\
\hline & Total & 30 & & & & & & \\
\hline
\end{tabular}

According to Mann-Whitney U-test results, by which post-test scores of the test and control groups were compared (Table 6), there is a significant difference $(\mathrm{p}<.05)$ in favor of the test group in all dimensions of Mentor Training Questionnaire. Also the mean scores in favor of the control group in "class management" and "communication" sub-dimensions (Table 5), resulted in the test group with a significant difference in the posttests (Table 6).

In consideration of $\mathrm{p}<.05$ significance level and the mean scores, the mentor candidates participating in Practicing Teacher Training Program were found to have higher competence levels with regard to practice teaching as compared to those who did not participate. This finding is an indication of the effectiveness of Practice Teaching Program in increasing the competences regarding mentoring.

Results Obtained from the Questionnaire for Practice Teaching Attitude: "Questionnaire for Practice Teaching Attitude" was applied as pretest and posttest on test and control groups prior to the implementation of "Mentor Training Program", to gain insight as to the level of favorable or negative approaches of participants about mentorship before and after the training. 
Table 7.

Pretest Results of Mentor Candidates Regarding Their Practice Teaching Attitudes

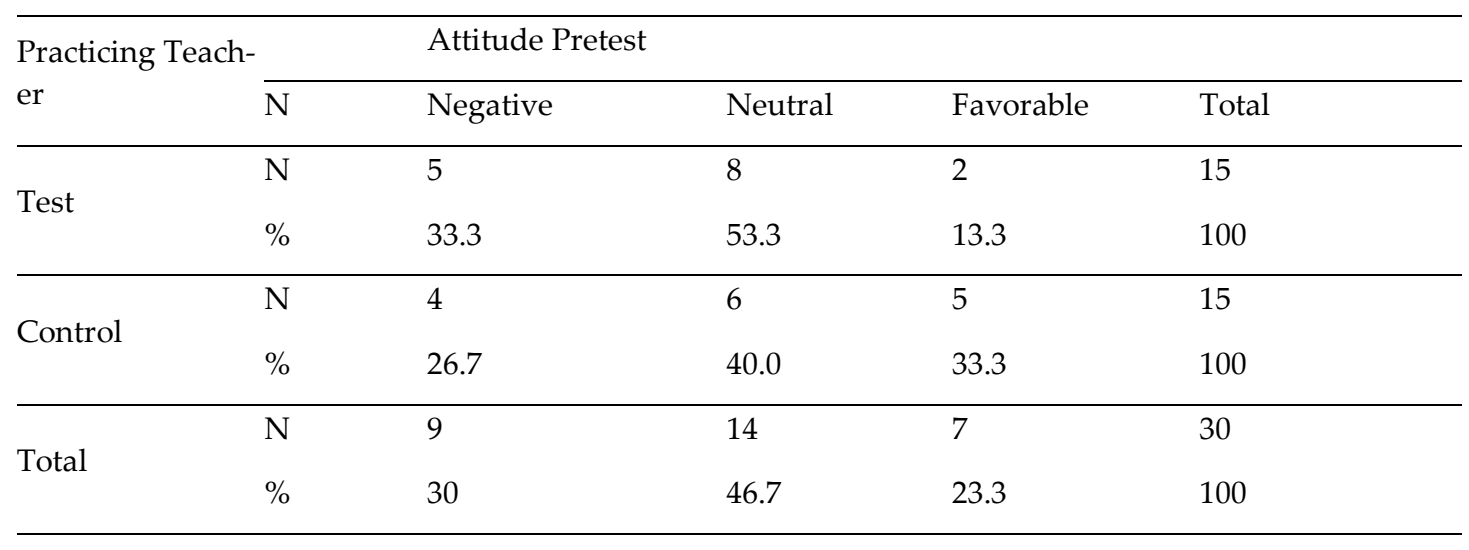

As indicated in Table 7, 53\% of test group practicing teachers and $40 \%$ of control group practicing teachers were found to have neutral attitudes towards practice teaching.

\section{Table 8 .}

The Differences in the Attitudes of Test and Control Groups towards Practice Teaching Before and After the Training

\begin{tabular}{|c|c|c|c|c|c|c|c|}
\hline Practicing Teacher & Group & $\mathrm{N}$ & Mean Rank & $\begin{array}{l}\text { Total } \\
\text { Rank. }\end{array}$ & $\begin{array}{l}\text { Mann } \\
\text { Whitney-U }\end{array}$ & Z & $p$ \\
\hline \multirow{3}{*}{$\begin{array}{l}\text { Attitude } \\
\text { Pre-test }\end{array}$} & Test & 15 & 14.07 & 211.00 & \multirow{3}{*}{91} & \multirow{3}{*}{-.962} & \multirow{3}{*}{.389} \\
\hline & Control & 15 & 16.93 & 254 & & & \\
\hline & Total & 30 & & & & & \\
\hline \multirow{3}{*}{$\begin{array}{l}\text { Attitude } \\
\text { Post-test }\end{array}$} & Test & 15 & 18.83 & 282.50 & \multirow{3}{*}{62} & \multirow{3}{*}{-2.287} & \multirow{3}{*}{.03} \\
\hline & Control & 15 & 12.17 & 182.50 & & & \\
\hline & Total & 30 & & & & & \\
\hline
\end{tabular}

As seen in Table 8 , there is no significant difference ( $p>.05)$ between the test and control groups with regard to practice teaching before and after the training. As also indicated by the ranking averages, the groups displayed similar attitude levels regarding practice teaching.

Also, a significant difference $(\mathrm{p}<.0,5)$ is observed between the final attitudes of the test and control groups. Also, the increase in mean rankings seems to be in favor of the test group. It can be inferred from these findings that, Practice Teaching Training Program provided the test group practicing teach- 
ers with a positive attitude towards mentoring. The difference in the attitudes of the test group before and after the training is also an indication of a positive change $(\mathrm{p}<.05)$ (Table 9$)$.

\section{Table 9.}

The Differences in the Attitudes of the Test Group Practicing Teachers towards Practice Teaching Before and After the Training (Single sample)

\begin{tabular}{|c|c|c|c|c|c|c|}
\hline Test Group & & $\mathrm{N}$ & Mean Rank. & Total Rank. & $Z$ & $p$ \\
\hline & -Rankings & 0 & .00 & .00 & \multirow{4}{*}{-2.919} & \multirow{4}{*}{.00} \\
\hline & + Rankings & 10 & 5.50 & 55.00 & & \\
\hline \multirow{2}{*}{ Post-test } & Ties & 5 & & & & \\
\hline & Total & 15 & & & & \\
\hline
\end{tabular}

According to the obtained findings, Mentor Training Program provided mentor candidates with positive attitude with regard to practice teaching.

\section{Evaluation of Mentor Training Program}

Two years after the completion of the experimental stage of the research, the test group teachers, still carrying out their duty, were subjected to monitoring test with the same measurement tools to evaluate the permanence of Mentor Training Program. Posttest scores (2007 Mentor Competence Questionnaire post-test score and Questionnaire for Practice Teaching Attitude post test score) were reused in each monitoring test application and these were then compared with the test scores of years 2009, 2012 and 2015.

The Results Obtained from Practicing Teacher Competence Questionnaire: 2007 overall scores of the test group were compared with 2009 overall scores and mentors were found to feel competent in the six subdimensions of the measurement tool (Table 10).

Table 10.

2009 Feedback of Practicing Teacher Competence Questionnaire

\begin{tabular}{llllll}
\hline Practicing Teachers & & N & Total Rank. & Z & \\
& & & & \\
& -Rankings & $0(\mathrm{a})$ & & & \\
Preparedness for Teaching Practices & + Rankings & $13(\mathrm{~b})$ & 110 & $-3.531(\mathrm{a})$ & .00 \\
Pretest - posttest & Ties & $0(\mathrm{c})$ & & \\
& Total & 15 & & \\
\hline
\end{tabular}




\begin{tabular}{|c|c|c|c|c|c|}
\hline & -Rankings & $0(\mathrm{~d})$ & & \multirow{4}{*}{$-3.286(a)$} & \multirow{4}{*}{1} \\
\hline Vocational Counseling & + Rankings & 13(e) & 91 & & \\
\hline \multirow[t]{2}{*}{ Pretest - posttest } & Ties & $2(\mathrm{f})$ & & & \\
\hline & Total & 15 & & & \\
\hline & -Rankings & $0(\mathrm{~g})$ & & \multirow{4}{*}{$-3.286(a)$} & \multirow{4}{*}{1} \\
\hline Evaluation & + Rankings & 13(h) & 91 & & \\
\hline \multirow[t]{2}{*}{ Pretest - posttest } & Ties & 2(i) & & & \\
\hline & Total & 15 & & & \\
\hline \multirow{4}{*}{$\begin{array}{l}\text { Observation } \\
\text { Pretest - posttest }\end{array}$} & -Rankings & $0(\mathrm{j})$ & \multirow{4}{*}{120} & \multirow{4}{*}{$-3.508(a)$} & \multirow{4}{*}{.00} \\
\hline & + Rankings & $15(\mathrm{k})$ & & & \\
\hline & Ties & $0(1)$ & & & \\
\hline & Total & 15 & & & \\
\hline \multirow{4}{*}{$\begin{array}{l}\text { Adult Education } \\
\text { Pretest - posttest }\end{array}$} & -Rankings & $0(\mathrm{~m})$ & \multirow{4}{*}{120} & \multirow{4}{*}{$-3.520(a)$} & \multirow{4}{*}{.00} \\
\hline & + Rankings & $15(\mathrm{n})$ & & & \\
\hline & Ties & $0(\mathrm{o})$ & & & \\
\hline & Total & 15 & & & \\
\hline \multirow{4}{*}{$\begin{array}{l}\text { Classroom Management } \\
\text { Pretest - posttest }\end{array}$} & -Rankings & $0(p)$ & \multirow{4}{*}{120} & \multirow{4}{*}{$-3.508(a)$} & \multirow{4}{*}{.00} \\
\hline & + Rankings & $15(\mathrm{q})$ & & & \\
\hline & Ties & $0(\mathrm{r})$ & & & \\
\hline & Total & 15 & & & \\
\hline \multirow{4}{*}{$\begin{array}{l}\text { Communication } \\
\text { Pretest-posttest }\end{array}$} & -Rankings & $0(\mathrm{~s})$ & \multirow{4}{*}{120} & \multirow{4}{*}{$-3.507(a)$} & \multirow{4}{*}{.00} \\
\hline & + Rankings & $15(\mathrm{t})$ & & & \\
\hline & Ties & $1(\mathrm{u})$ & & & \\
\hline & Total & 15 & & & \\
\hline \multirow{4}{*}{$\begin{array}{l}\text { Feedback } \\
\text { Pretest - posttest }\end{array}$} & -Rankings & $0(\mathrm{v})$ & \multirow{4}{*}{91} & \multirow{4}{*}{$-3.314(a)$} & \multirow{4}{*}{1} \\
\hline & + Rankings & $13(w)$ & & & \\
\hline & Ties & $2(x)$ & & & \\
\hline & Total & 15 & & & \\
\hline \multirow{4}{*}{$\begin{array}{l}\text { Personal Attributes } \\
\text { Pretest - posttest }\end{array}$} & -Rankings & $0(\mathrm{y})$ & & \multirow{4}{*}{$-3.508(a)$} & \multirow{4}{*}{.00} \\
\hline & + Rankings & $15(z)$ & 120 & & \\
\hline & Ties & $0(\mathrm{aa})$ & & & \\
\hline & Total & 15 & & & \\
\hline
\end{tabular}


As seen in Table 10, mentors feel competent $(\mathrm{p}<.05)$ in the dimensions of "preparedness for teaching practices", "observation", classroom management", "adult education", "communication" and "personal attributes", whereas they feel incompetent in the sub-dimensions of "vocational counseling", "evaluation", and "feedback" sub-dimensions.

The vocational counseling, provided feedback, and performed evaluation throughout the teaching practices require teacher candidates to have technical knowledge and content. These sub-dimensions break out of the educational routine of a mentor as a primary school teacher as compared to other subdimensions. This, accordingly, accounts for the mentors' opinions as to being incompetent in the course of time.

The Results Obtained from the Questionnaire for Practice Teaching Attitude: The participants, trained in 2007 as mentors and provided with the positive attitude towards mentoring were found to maintain their positive attitude in year 2009 (Table 11).

Table 11.

2009 Feedback of the Mentoring Attitude Questionnaire

\begin{tabular}{|c|c|c|c|c|c|}
\hline Test Group & & $\mathrm{N}$ & Mean Rank. & Total ranking. Z & $\mathrm{p}$ \\
\hline & -Rankings & 0 & .00 & .00 & \\
\hline Attitude & + Rankings & 10 & 5.50 & 55.00 & \\
\hline Pretest & Ties & 5 & & -2.919 & .00 \\
\hline Posttest & Total & 15 & & & \\
\hline
\end{tabular}

As seen in Table 11, practicing teachers were eager to aid teacher candidates.

\section{Evaluation of Mentor Training Program}

Total scores of 2007 questionnaires for mentors' mentoring competencies and attitudes towards mentoring were compared with the total scores of 2012.

The Results Obtained From Practicing Teacher Competence Questionnaire: Practicing teachers were found to feel competent in the "preparedness for teaching practices", "classroom management", and "personal attributes" sub-dimensions even though they received their education 5 years before (Table $12)$.

Table 12.

2012 Evaluation of Practicing Teacher Competence Questionnaire

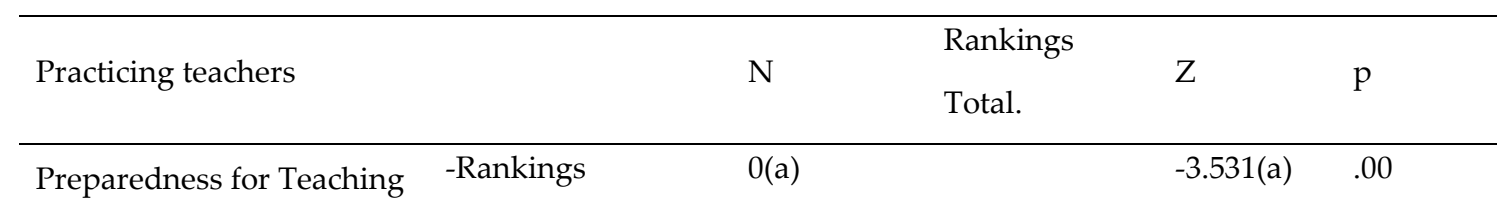




\begin{tabular}{|c|c|c|c|c|c|}
\hline Practices & + Rankings & $15(b)$ & 120 & & \\
\hline \multirow[t]{3}{*}{ Pretest - posttest } & Ties & $0(\mathrm{c})$ & & & \\
\hline & Total & 15 & & & \\
\hline & -Rankings & $0(d)$ & & \multirow{4}{*}{$-3.286(a)$} & \multirow{4}{*}{1} \\
\hline Vocational Counseling & + Rankings & $13(\mathrm{e})$ & 91 & & \\
\hline \multirow[t]{3}{*}{ Pretest - posttest } & Ties & $2(f)$ & & & \\
\hline & Total & 15 & & & \\
\hline & -Rankings & $0(\mathrm{~g})$ & & \multirow{4}{*}{$-3.286(a)$} & \multirow{4}{*}{1} \\
\hline Evaluation & + Rankings & $13(\mathrm{~h})$ & 91 & & \\
\hline \multirow[t]{3}{*}{ Pretest - posttest } & Ties & 2(i) & & & \\
\hline & Total & 15 & & & \\
\hline & -Rankings & $3(\mathrm{j})$ & & \multirow{4}{*}{$-3.372(a)$} & \multirow{4}{*}{1} \\
\hline Observation & + Rankings & $10(\mathrm{k})$ & 104 & & \\
\hline \multirow[t]{2}{*}{ Pretest - posttest } & Ties & $2(1)$ & & & \\
\hline & Total & 15 & & & \\
\hline \multirow{4}{*}{ Pretest - posttest } & -Rankings & $0(\mathrm{~m})$ & \multirow{4}{*}{120} & \multirow{4}{*}{$-3.520(a)$} & \multirow{4}{*}{.00} \\
\hline & + Rankings & $15(n)$ & & & \\
\hline & Ties & $0(\mathrm{o})$ & & & \\
\hline & Total & 15 & & & \\
\hline \multirow{4}{*}{$\begin{array}{l}\text { Classroom Management } \\
\text { Pretest - posttest }\end{array}$} & -Rankings & $0(\mathrm{p})$ & & \multirow{4}{*}{$-3.508(\mathrm{a})$} & \multirow{4}{*}{.00} \\
\hline & + Rankings & $15(q)$ & 120 & & \\
\hline & Ties & $0(\mathrm{r})$ & & & \\
\hline & Total & 15 & & & \\
\hline \multirow{4}{*}{$\begin{array}{l}\text { Communication } \\
\text { Pretest - posttest }\end{array}$} & -Rankings & $0(\mathrm{~s})$ & & \multirow{4}{*}{$-3.391(a)$} & \multirow{4}{*}{1} \\
\hline & + Rankings & $14(\mathrm{t})$ & 105 & & \\
\hline & Ties & $1(\mathrm{u})$ & & & \\
\hline & Total & 15 & & & \\
\hline \multirow{4}{*}{$\begin{array}{l}\text { Feedback } \\
\text { Pretest - posttest }\end{array}$} & -Rankings & $0(\mathrm{v})$ & & \multirow{4}{*}{$-3.314(a)$} & \multirow{4}{*}{1} \\
\hline & + Rankings & $13(w)$ & 91 & & \\
\hline & Ties & $2(x)$ & & & \\
\hline & Total & 15 & & & \\
\hline Personal Attributes & -Rankings & $0(y)$ & & \multirow{2}{*}{$-3.508(a)$} & \multirow{2}{*}{.00} \\
\hline Pretest - posttest & + Rankings & $15(z)$ & 120 & & \\
\hline
\end{tabular}


Ties $\quad 0$ (aa)

Total 15

In 2009 mentors considered themselves incompetent in vocational counseling, evaluation and feedback sub-dimensions, and after the period of five years "observation" and "communication" sub-dimensions were also included in to these sub-dimensions (Table 12). In the course of time, the losses in the fields that require more technical and effective knowledge for mentoring becomes more evident (Table 12).

The Results Obtained from the Questionnaire for Practice Teaching Attitude: Teacher candidates were found to have maintained their positive attitude towards mentoring (Table 13).

Table 13.

Mentoring Attitude Questionnaire Feedback for 2012.

\begin{tabular}{lllllll}
\hline Test group & & $\mathrm{N}$ & Aver. Rank. & Total Rankings. & $Z$ & $p$ \\
& & & & & & \\
\hline Attitude & -Rankings & 0 & .00 & .00 & & \\
Pretest & + Rankings & 10 & 5.50 & 55.00 & -2.919 & .00 \\
Posttest & Ties & 5 & & & & \\
& Total & 15 & & & \\
\hline
\end{tabular}

Mentors were found to be still disposed to undertake the task of practice teaching even though five years passed since the experimental period (see Table 13).

\section{Evaluation of Mentor Training Program}

Due to the retirement of two mentors, evaluation of the training program for year 2015 was performed with 13 mentors using Practicing Teacher Competence Questionnaire and Practice Teaching Attitudes Questionnaire.

The Findings Obtained From Practicing Teacher Competence Questionnaire: In the last application of the evaluation tool, mentors were found to regard themselves competent in terms of "adult education", "classroom management" and "personal attributes", and in competent in the other six sub-dimensions (Table 14). 


\section{Table 14.}

2012 Evaluation of Practicing Teacher Competence Questionnaire

\begin{tabular}{|c|c|c|c|c|c|}
\hline Practicing Teachers & & $\mathrm{N}$ & $\begin{array}{l}\text { Rank. } \\
\text { Total }\end{array}$ & $z$ & $p$ \\
\hline \multirow{4}{*}{$\begin{array}{l}\text { Preparedness for Teaching } \\
\text { Practices } \\
\text { Pretest - posttest }\end{array}$} & -Rankings & $0(a)$ & \multirow{4}{*}{91} & \multirow{4}{*}{$-3.508(a)$} & \multirow{4}{*}{1} \\
\hline & + Rankings & $13(b)$ & & & \\
\hline & Ties & $0(\mathrm{c})$ & & & \\
\hline & Total & 13 & & & \\
\hline \multirow{4}{*}{$\begin{array}{l}\text { Vocational Counseling } \\
\text { Pretest - posttest }\end{array}$} & -Rankings & $0(\mathrm{~d})$ & \multirow{4}{*}{91} & \multirow{4}{*}{$-3.508(a)$} & \multirow{4}{*}{1} \\
\hline & + Rankings & 13(e) & & & \\
\hline & Ties & $0(\mathrm{f})$ & & & \\
\hline & Total & 13 & & & \\
\hline \multirow{4}{*}{$\begin{array}{l}\text { Evaluation } \\
\text { Pretest - posttest }\end{array}$} & -Rankings & $0(\mathrm{~g})$ & \multirow{4}{*}{91} & \multirow{4}{*}{$-3.286(a)$} & \multirow{4}{*}{1} \\
\hline & + Rankings & 11(h) & & & \\
\hline & Ties & 2(i) & & & \\
\hline & Total & 13 & & & \\
\hline \multirow{4}{*}{$\begin{array}{l}\text { Observation } \\
\text { Pretest - posttest }\end{array}$} & -Rankings & $0(\mathrm{j})$ & \multirow{4}{*}{91} & \multirow{4}{*}{$-3.508(a)$} & \multirow{4}{*}{1} \\
\hline & + Rankings & $13(\mathrm{k})$ & & & \\
\hline & Ties & $0(1)$ & & & \\
\hline & Total & 13 & & & \\
\hline \multirow{4}{*}{$\begin{array}{l}\text { Adult Education } \\
\text { Pretest - posttest }\end{array}$} & -Rankings & $0(\mathrm{~m})$ & & \multirow{4}{*}{$-3.508(a)$} & \multirow{4}{*}{.00} \\
\hline & + Rankings & $13(n)$ & 120 & & \\
\hline & Ties & $0(\mathrm{o})$ & & & \\
\hline & Total & 13 & & & \\
\hline \multirow{4}{*}{$\begin{array}{l}\text { Classroom Management } \\
\text { Pretest - posttest }\end{array}$} & -Rankings & $0(p)$ & \multirow{4}{*}{120} & \multirow{4}{*}{$-3.508(a)$} & \multirow{4}{*}{.00} \\
\hline & + Rankings & $13(q)$ & & & \\
\hline & Ties & $0(\mathrm{r})$ & & & \\
\hline & Total & 13 & & & \\
\hline \multirow{4}{*}{$\begin{array}{l}\text { Communication } \\
\text { Pretest - posttest }\end{array}$} & -Rankings & $0(\mathrm{~s})$ & & \multirow{4}{*}{$-3.391(a)$} & \multirow{4}{*}{1} \\
\hline & + Rankings & $12(t)$ & 105 & & \\
\hline & Ties & $1(\mathrm{u})$ & & & \\
\hline & Total & 13 & & & \\
\hline Feedback & -Rankings & $0(\mathrm{v})$ & & $-3.314(a)$ & 1 \\
\hline
\end{tabular}




\begin{tabular}{|c|c|c|c|c|c|}
\hline \multirow[t]{3}{*}{ Pretest - posttest } & + Rankings & $11(w)$ & \multirow[t]{3}{*}{91} & & \\
\hline & Ties & $2(x)$ & & & \\
\hline & Total & 13 & & & \\
\hline & -Rankings & $0(\mathrm{y})$ & & \multirow{4}{*}{$-3.508(a)$} & \multirow{4}{*}{.00} \\
\hline Personal Attributes & + Rankings & $13(z)$ & 120 & & \\
\hline \multirow[t]{2}{*}{ Pretest - posttest } & Ties & $0(\mathrm{aa})$ & & & \\
\hline & Total & 13 & & & \\
\hline
\end{tabular}

8 years after being trained as practicing teacher (mentor), classroom teachers stated that they felt competent in terms of "adult education", "classroom management" and "personal attributes", while they did not consider themselves competent in the six other sub-dimensions (Table 14).

In 2012 evaluation term, mentors considered themselves compeetent in "preparedness for teaching practices" while in 2015 they stated the opposite (Table 14). Accordingly it can be inferred that practicing candidates' competences declined in time.

The Results Obtained From Practice Teaching Attitudes Questionnaire: Mentors were found to maintain their positive attitude towards practice teaching eight years after their training (Table 15).

\section{Table 15.}

2015 Feedback of Mentoring Attitude Questionnaire

\begin{tabular}{lllllll}
\hline Test Group & & $\mathrm{N}$ & & Mean Rank. Total Rank. Z & $p$ \\
& & & & & \\
Attitude & -Rankings & 0 & .00 & .00 & & \\
Pre-test & + Rankings & 10 & 5.50 & 55.00 & -2.919 & .00 \\
Post-test & Ties & 5 & & & & \\
& Total & 15 & & & & \\
\hline
\end{tabular}

\section{DISCUSSION}

Mentor Training Program proved to be effective in terms practice teaching in the short and medium terms, while in the long term it was found to be partly effective, and in terms of attitude towards practice teaching it proved to be effective in the short, medium and long terms. Accordingly, mentor training program proved to be more effective on affective behaviors as compared to mentor competences.

In the first stage of the research, eight years before the present study, the attitudes of test and control groups towards mentoring was found to be "neutral" and it remarkably became and remained favorable within the following eight years. As an affective dimension "attitude" holds particular importance in raising eagerness with regard to mentoring, since in an ambitiously performed practice teaching process, mentors undertake an encouraging and aspirational role in terms of knowledge, skill and profes- 
sion within the frame of professional development of teacher candidates (AIR, 2015). This role is essential in terms of effective accomplishment of practicing period and acquisition of a positive attitude towards teaching by teacher candidates which results in an increased student success.

Accordance of the learning modules of the training program with "Practicing Teacher Competence Questionnaire" and "Practice Teaching Attitudes Questionnaire" had a positive impact on the research results. The teaching approach, method, technique, teaching aids and classroom/seating arrangement applied in the course of training are also important yet non-measured variables, which are assumed to have an impact on the obtained results through being in accordance with the objectives and behaviors of the learning module. Implementation of the training program in line with the adult education principles and application of each module by the content professionals also had an influence on the results. Briefly, the accomplishment period of targets/behaviors provided unity in terms of the used content, approach, method, technique and the physical classroom conditions, thus having a positive influence on permanence. The program's ability to develop the collaboration and sense of confidence between practicing teachers and teacher candidates is another factor contributing to its permanence, since confidence-based communication, cooperation and democratic approach are indications of a fair mentoring period (Gardiner, 2011). For such reasons, "practicing teacher personal attributes" and "adult education" subdimensions of the Practicing Teacher Competence Questionnaire maintained its permanence. The obtained result is also verified through the accordance of the mentioned sub-dimensions with the properties of the Practice Teaching Attitudes Questionnaire. These variables' co-existence in spite of the elapsed period is also noteworthy. The most important factor, contributing to the obtained result is considered as the scientific basis provided via determination of the need for training mentors across the country, and development-implementation of Practicing Teacher Training Program in line with this requirement. This is also attributable to consideration of the possible consequences (Catapano, 2006) of mentor training programs and teaching practices developed and implemented in line with the cultural attributes, which in turn necessarily influenced the mentor training program (Kochan, 2013; Ofsted, 2014), thus yielding intrinsically favorable results. Briefly, accordance of the Practicing Teacher Training Program with the requirements and the cultural attributes rendered this program an effective means.

In the progress of teaching practices, the mentorship efforts especially made by primary school teachers becomes more challenging in terms of development period attributes of students, compared to branch teachers. This can be ascribed to difficulties faced by teachers in transition from "pedagogical" approach, as the educational process of their own students, to "adulthood/andragogical" approach, as the interaction with teacher candidates to whom they provide mentoring. Achievement and maintenance of this transitional period with Practicing Teacher Training Program is another proof for the program's success.

The effective use of "classroom management" sub-dimension, in competency dimensions, can be attributed to uncontrollable variables, since classroom management may be quite preoccupying for teachers. In this research, however, through suitable techniques, mentors are equipped with an insight into setting a classroom environment that promotes learning, implementing a democratic sense of discipline, as well as in-depth knowledge on the effect of a primary school teacher's knowledge and technical qualities on classroom management processes. All these achievements contributed to the permanence of the program. Also, mentors exhibited the highest level of positive change in "classroom management" dur- 
ing the mentoring program which was performed with 1600 teacher candidates and 700 mentors from 56 schools (Iris \& Sadlin, 2002), which supports the findings obtained from this research.

\section{REFERENCES}

Ambrosetti, A., Knight, B. A., \& Dekkers, J. (2014). Maximizing the potential of mentoring: a framework for pre-service teacher education. Mentoring ETutoring: Partnership in Learning, 22(3), 224-239.

American Institues For Research (2015). Promoting Teacher Effectivenss Teacher Induction and Mentoring Brief. July.

AERA (2005). The Impact of New Teacher Induction on Teacher Practices and Student Learning. Annual Meeting of the American Educational Research Association. Montreal April 13, Unpublished Work.

Breaux, A., \& Wong, H. (2003). New teacher induction: How to train, support and retain new teachers. Mountain View, CA: Harry K. Wong Publications.

Captapano, S (2006). Teaching in urban schools: Mentoring pre-service teachers to apply advocacy strategies. Mentoring and Tutoring, 14, 81-96.

Clark, S. K. (2012). Through the eyes of the novice teacher: Perceptions of mentoring support. Part of the Teacher Education and Professional Development Commons. Retrieved October, 2016, from http://digitalcommons.usu.edu/teal_facpub

Duckworth, V., \& Maxwell, B. (2015) Extending the mentor role in initial teacher education: embracing social justice. International Journal of Mentoring and Coaching in Education, 4(1), 4-20.

Farral, S. (2004). What is qualitative longitudinal research? London school of economics and political science methodology institute papers in social research methods qualitative series. No 11, Retrieved May, 2016, from http://www.lse.ac.uk/methodology/pdf/QualPapers/Stephen-FarrallQualLongitudinal Res.pdf.

Gardiner, W (2011), Mentoring in an urban teacher residency: Mentors' persepcions of year-long placements. New Educator, 7(2), 153-171.

Gershenfeld, S. (2014). A review of undergraduate mentoring programs. Review of Educational Research, $84(3), 365-391$.

Harry K. Wong, Induction Programs That Keep New Teachers Teaching and Improving NASSP Bulletin _ Vol. $88 \mathrm{~N}$

Kochan, F. (2013). Analyzing the relationships between culture and mentoring. Mentoring ETutoring: Partnership in Learning, 21(4), 412-430.

Moir, E, \& Gless, J. (2004). Quality Induction: An investment in Teachers. New Teacher Center, http://www.newteachercenter.org/article-CCETQInd.html. 
Odell, S. J., Huling,L., Sweeny, B. (1999). Conceptualizing guality mentoring: Background information. Indianapolis, IN:Kappa Delta Pi.

OFSTED (2014), Initial Teacher Education (ITE) Inspecion Handbook. Retrieved November, 2016, from www.ofsted.gov.uk/resources/initial-teacher-education-inspection-handbook,

Riggs, I., M., \& Sandlin, R. (2002). A Professional Development of Mentors within a Beginning Teacher Induction Program: How Does the Garden (Mentors) Grow? Retrieved May, 2016, http://files.eric.ed.gov/fulltext/ED465752.pdf, 2005,

Rivkin, S. G, \& Hanushek, E. A (2005). Teachers, schools and academic achievement. Econometrica, 73(2).

Rockoff, J. E. (2004). The impact of individual teachers on student achivement: Evidence from panel data. The American Economic Review, 94(2).

Strong, M. (2005). Mentoring new teachers to increase retention. New Teacher Center Research Brief 5(1). Retrieved from http://www.newteachercenter.org/sites/default/files/ntc/main/resources

Smith, C., Hofer, J., Gillespie, M., Solomon, M., \& Rowe, K. (2003). How teachers change: A study of professional development in adult education. NCSALL Research Brief. Retrieved from http://www.ncsall.net/fileadmin/resources/research/brief25.pdf )

Sutherland, L. M., Scanlon, L. A., \& Sperring, A. (2005). New directions in preparing professionals:examing issues in engaging students in communities of practise through a school-university partnership. Teaching and teacher Education, 21, 79-92.

Wong, H. (2004). Induction programs that keep new teachers teaching and improving. NASSP, Bulletin, 87(638).

Yalın Ucar, M. (2007). Uygulama öğretmeni (mentör) yetiştirme programının etkililiğ̆i, TÜBİTAK Bilimsel ve Teknolojik Araştırma Projelerini Destekleme Programı, 106K075.

Yalın Uçar, M. (2007). Sınıf öğretmenlerinin hizmet öncesi eğitiminde yer alan staj uygulamalarının değerlendirilmesi. Yayınlanmamış EARGED projesi, MEB, Protokol, 2006/1, 2007. 